\title{
Effect of different curing conditions on the mechanical properties of reactive powder concrete
}

\author{
Mazin Abdulrahman ${ }^{1, *}$, Alyaa Al-Attar ${ }^{2}$ and Marwa Ahmad ${ }^{2}$ \\ ${ }^{1}$ Civil Engineering Department, Tikrit University, Tikrit, Iraq \\ ${ }^{2}$ Technical College, Kirkuk, Iraq
}

\begin{abstract}
Reactive Powder Concrete (RPC) is an ultra-high performance concrete which has superior mechanical and physical properties, and composed of cement and very fine powders such as quartz sand and silica fume with very low water/ binder ratio and Superplasticizer. Heat treatment is a well-known method that can further improve the performance of (RPC). The current research including an experimental study of the effect of different curing conditions on mechanical properties of reactive powder concrete (compressive strength, modulus of rupture and splitting tensile strength), the curing conditions includes three type of curing; immersion in water at temperature of $35^{\circ} \mathrm{C}$ (which is considered as the reference-curing situation), immersion in water at temperature of $90^{\circ} \mathrm{C}$ for 5 hours daily and curing with hot steam for 5 hours daily) until 28 days according to ASTM C684-99 [8]. This research includes also the study of effect of adding silica fume as percentage of cement weight on mechanical properties of reactive powder concrete for different percentage ratios $(5 \%, 10 \%$ and $15 \%)$. Super plasticizer is also used with ratio of $(1.8 \%)$ by weight of cementitious material; constant water cement ratio (0.24) was used for all mixes. For each reactive concrete mix, it has been cast into a cubes of $(150 * 150 * 150)$ (to conduct the compression test), a cylinders of $150 \mathrm{~mm}$ diameter with $300 \mathrm{~mm}$ height (to conduct split test) and prisms of $(500 * 100 * 100) \mathrm{mm}$ to conduct the modulus of rupture test. The results showed that the best method of curing (according to its enhancing the RPC mechanical properties) is the method of immersion in hot water at temperature $90{ }^{\circ} \mathrm{C}$ for the all silica fume percentages, and the best used silica fume percentage was $(10 \%)$ for the all used curing methods.
\end{abstract}

\section{Introduction}

The conventional concrete has a compressive strength of usually less than $40 \mathrm{MPa}$. It is relatively brittle and its resistant to plastic deformation is relatively low and have low tensile strength and the cracks appears fast. Also, conventional concrete is heavy somewhat and have low resistance to vibration loads. Thus, the designers and construction professionals sought to introduce new ideas and approaches that would make the concrete more efficient. Recently, a new generation of concrete with excellent characteristics and properties called High Performance Concrete (HPC)have been developed [1].

The Reactive Powder Concrete RPC, which was manufactured in France in the 1990s is a new type of high performance concrete which has good mechanical properties and durability [2] [3]. The major difference between reactive powder concrete and conventional concrete is that no coarse aggregate is involved in reactive powder concrete, but crushed quartz and quartz sand are used instead, with a high dosage of silica fume. So that all materials are granular size less than 600 micrometers.
The advanced mechanical and physical properties of RPC are obtained by optimizing packing density of concrete mixture with fine gradation of all mix particles, and by using highly refined silica fume to improve the microstructure of hydrated cement paste through the pozzolanic reaction. The granular size less than 600 micrometers and can be widely used in structural engineering applications, especially in locations where large loads generate tension stresses and high cutting forces.

Furthermore, researchers reported that application of different heat cure processes improve mechanical properties of RPC [4] The aim of the heat treatment of concrete is to increase the hydration speed and thus decrease the setting and hardening period. Besides conventional water curing (standard) of setting concrete, resistance can be gained in a shorter time with different curing methods. These kinds of cures that facilitate the resistance gaining are generally categorized as heat treatment [5]. Thus, heat treatment is a well-known method that can further improve the performance of (RPC).

\footnotetext{
* Corresponding author:dr.mazinburhan @tu.edu.iq
} 


\section{Objective of research}

1- Studying the possibility of producing reactive powder concrete.

2- Studying the effect of different curing methods on the properties of hardened concrete (compressive strength, split strength and the modulus of rupture). The treatments used include ordinary treatment by immersion in water at $35^{\circ} \mathrm{C}$ and immersion in hot water treatment at $90{ }^{\circ} \mathrm{C}$ for 5 hours per day and steam treatment for 5 hours per day according to ASTM C684-99 [8] until testing of samples.

3- Study the effect of the addition of silica fume at different ratios $(5 \%, 10 \%, 15 \%)$ by cement weight on the mechanical properties of (RPC).

\section{Experimental program}

\subsection{Material used}

\subsubsection{Cement}

Local Iraqi cement was used (Type mass), which is an ordinary Portland cement. The results of the test were in accordance with the Iraqi standard specifications (IQS No.5/1984) [9]. The physical and chemical properties of this cement are shown in Table (1).

Table 1. Physical and chemical properties of cement

\begin{tabular}{ccc}
\hline \hline Properties & Value & $\begin{array}{c}\text { Limits of IQ Specification } \\
5 / 1984[9]\end{array}$ \\
\hline $\begin{array}{c}\text { Specific Surface Area } \\
\text { Initial Setting Time } \\
\text { (min.) }\end{array}$ & 259 & 230 lower limit \\
$\begin{array}{c}\text { Not less than } 45 \text { min. } \\
\text { Ninal Setting Time (hr.) }\end{array}$ & 5 & \\
Compressive Strength & 23.6 & $(15 \mathrm{Mpa})$ \\
(MPa) at age of 3 days. & & - \\
$\mathrm{CaO}$ & $61.44 \%$ & $8 \%$ upper limit \\
$\mathrm{Al}_{2} \mathrm{O}_{3}$ & $4.1 \%$ & $5 \%$ upper limit \\
$\mathrm{SiO}_{2}$ & $3.93 \%$ & $4 \%$ upper limit \\
$\mathrm{SO}_{3}$ & $1.21 \%$ & $5 \%$ upper limit \\
$\mathrm{Fe}_{2} \mathrm{O}_{3}$ & $3.93 \%$ & $2.5 \%$ upper limit \\
$\mathrm{MgO}^{2}$ & $2.46 \%$ & $4 \%$ upper limit \\
$\mathrm{L} \mathrm{O} . \mathrm{I}$ & $1.26 \%$ & - \\
$\mathrm{I} . \mathrm{R}$ & $0.78 \%$ & $1.5 \%$ upper limit \\
$\mathrm{C}_{3} \mathrm{~S}$ & $58.17 \%$ & - \\
$\mathrm{C}_{2} \mathrm{~S}$ & $16.34 \%$ & - \\
$\mathrm{C}_{3} \mathrm{~A}$ & $6.7 \%$ & - \\
$\mathrm{C}_{4} \mathrm{AF}$ & $13.28 \%$ & \\
& &
\end{tabular}

\subsubsection{Fine aggregate}

The sand used in the concrete mix is known as quartz sand of granular size (150-600) micrometer. The sand sieve analysis and its properties are shown in Tables 2 and 3 and it conforms to the British Specifications (B.S.882) [10].
Table 2 Grading of fine aggregate

\begin{tabular}{ccc}
\hline \hline $\begin{array}{c}\text { Sieve Size } \\
(\mathrm{mm})\end{array}$ & $\begin{array}{c}\text { Cumulative Passing } \\
\%\end{array}$ & $\begin{array}{c}\text { Limits of B.S.882 } \\
\text { (zone III) }\end{array}$ \\
\hline 4.75 & 100 & $90-100$ \\
2.36 & 92 & $85-100$ \\
1.18 & 83 & $75-100$ \\
0.6 & 62 & $60-79$ \\
0.3 & 23 & $12-40$ \\
0.15 & 5.25 & $0-10$ \\
\hline \hline
\end{tabular}

Table 3. physical and chemical properties of fine aggregates

\begin{tabular}{ccc}
\hline \hline properties & Test result & $\begin{array}{c}\text { Limit of Iraqi specification } \\
\text { No.5/1984 }\end{array}$ \\
\hline Specific gravity & 2.7 & ------ \\
Absorption & 0.7 & ----- \\
Sulphate content & 0.13 & $0.5(\max )$ \\
Materials finer than & 1.24 & $5(\max )$ \\
$0.075 \mathrm{~mm}$ & & \\
\hline \hline
\end{tabular}

\subsubsection{Water}

Ordinary tap water was used for mixing and curing all concrete mixes of this investigation.

\subsubsection{Silica fume}

Silica fume used in this research is type (silica fume HR). Silica fume is produced as a by-product of the silicon industry, which is 100 times finer than the Portland cement. When used in concrete, it is used as a filler and as cementitous material, where the Silica Fume's small particles fill the spaces between cement particles and between cement and aggregates. Silica fume also reacts with Calcium Hydroxide resulting from the process of cement hydration to form extra calcium silicate during the reaction, thus producing a denser, stronger and less permeable concrete. It was used in the form of addition to the cement as percentages of cement weight by $5 \%, 10 \%, 15 \%$. The used silica fume is of high quality, and is dependable as concrete additive according to the US specification (ASTM C1240-03) [11], Tables (4) and (5) illustrate the physical and chemical properties of this type of silica fume respectively.

Table 4. Physical properties of silica fume

\begin{tabular}{cc}
\hline property & Value \\
\hline Density & $300 \mathrm{~kg} / \mathrm{m}^{3}$ \\
form & powder \\
Appearance/ colour & Grey powder \\
\hline \hline
\end{tabular}

Table 5. Chemical properties of silica fume

\begin{tabular}{ccc}
\hline \hline property & Test Value & Limits According to ASTM \\
\hline SiO2 & $90 \%$ & $>85 \%$ \\
L.O.I & $2.86 \%$ & $<6 \%$ \\
\hline \hline
\end{tabular}




\subsubsection{Superplasticizer}

In this study, the super-plasticizer PC260 is used to enhance the early and final resistance of the concrete. The additive is highly effective for the production of reactive powder concrete. It gives good workability and flow-ability. This additive does not contain chlorides or any compounds that help to iron corrosion. Table (6) shows the specifications for this additive [12]. The additive is commercially known as PC260, which is different from the standard super-plasticizers, which consists of long chain polycarboxylic ether polymers, which makes the concrete smooth and gives high compressive strength and the plasticizer is suitable for use with ordinary Portland Cement.

Table 6. Specification of superplasticizer

\begin{tabular}{lc}
\hline \hline \multicolumn{1}{c}{ Main action } & Super-plasticizer properties \\
\hline Appearance & Light yellow liquid \\
Specific Gravity & $1.1 \pm 0.02$ \\
Viscosity & $22 \mathrm{cp}, 20 \mathrm{C}$ \\
Chloride Content & $0.1 \%$ \\
Chemical Base & Polycarboxylic either \\
& polymers \\
\hline \hline
\end{tabular}

\subsection{Design of concrete mix}

The key to the production of Reactive Powder Concrete (RPC) is the high cement content, glass sand (150-600) micrometer, and the ratio of water to cement is very low with high content of super plasticizer, where the mortar consisting of quartz sand, cement and silica fume have a great effect on providing high resistance. The concrete mix of reactive powder concrete is designed in order to obtain the highest compressive strength according to the ACI code ACI-211-91 [13]. The following quantities of contents are used: $990 \mathrm{~kg} / \mathrm{m}^{3}$ of ordinary Portland cement, $1090 \mathrm{~kg} / \mathrm{m}^{3}$ of the quartz sand content, 237.6 $\mathrm{kg} / \mathrm{m}^{3}$ the water content and $1.8 \%$ per $100 \mathrm{~kg}$ of cement of the plasticized ratio. Three ratios of silica fume as additives to cement has been used $(5 \%, 10 \%, 15 \%)$ in addition to the silica-free reference concrete. This plasticized ratio of $1.8 \%$ was used because it is the optimum ratio that gives the best operational reliability through the precipitation test. The mixing of concrete components is important for the required workability and the homogeneity of mix, and concrete mixing process affects the quality of the concrete at the hardened state and the mixture materials should be distribute regularly during concrete for reactive concrete powders. The steps of mixing are as follows: A mixer with a capacity of 0.1 $\mathrm{m}^{3}$ used, where cement and quartz sand are mixing together in there dry state for 3 minutes and then add silica fume and mixing there for another 5 minutes. The water and plasticizer are mixed separately and gradually added to the pre-mixed dry ingredients and mix all for 3 minutes.
Table 7. Ingredients of concrete mix

\begin{tabular}{ccccc}
\hline \multicolumn{5}{c}{ Ingredients kg/m3. } \\
\hline Water $\left(\mathrm{kg} / \mathrm{m}^{\prime}\right.$ & $\begin{array}{c}\text { Fine } \\
\text { aggregate } \\
\left(\mathrm{kg} / \mathrm{m}^{3}\right)\end{array}$ & $\begin{array}{c}\text { Cement } \\
\left(\mathrm{kg} / \mathrm{m}^{3}\right)\end{array}$ & $\begin{array}{c}\text { Silica } \\
\text { fume } \\
\left(\mathrm{kg} / \mathrm{m}^{3}\right)\end{array}$ & $\begin{array}{c}\text { Super } \\
\text { plasticizer } \\
\%\end{array}$ \\
237.6 & 1090 & 990 & 0 & 1.8 \\
237.6 & 1090 & 990 & 49.5 & 1.8 \\
237.6 & 1090 & 990 & 99 & 1.8 \\
237.6 & 1090 & 990 & 148.5 & 1.8 \\
\hline \hline
\end{tabular}

\subsection{Cast of samples}

After completion of the mixing process, the contents of the mix shall be emptied and poured into the molds using the iron molds set for this purpose. All molds shall be cleaned before casting. The inner faces of the molds shall be greased to prevent adhesion of the hardened concrete with the inner surface of the molds. The cubes and cylinders are casted in three layers whereas the prisms are casted in two layers and each layer is vibrated by the electric vibrator. After casting, the samples are placed in a dry place and covered with plastic sheeting to prevent plastic cracking due to shrinkage for 24-hour and then cured. The following samples where casted: three cubes of dimensions $(150 * 150 * 150) \mathrm{mm}$, three cylinders of dimensions $(500 * 300)$ and three prisms of dimensions $(100 * 100 * 500) \mathrm{mm}$. Thus, the number of models are (72) cubic, (72) cylinder and (72) prism, Fig. (1).

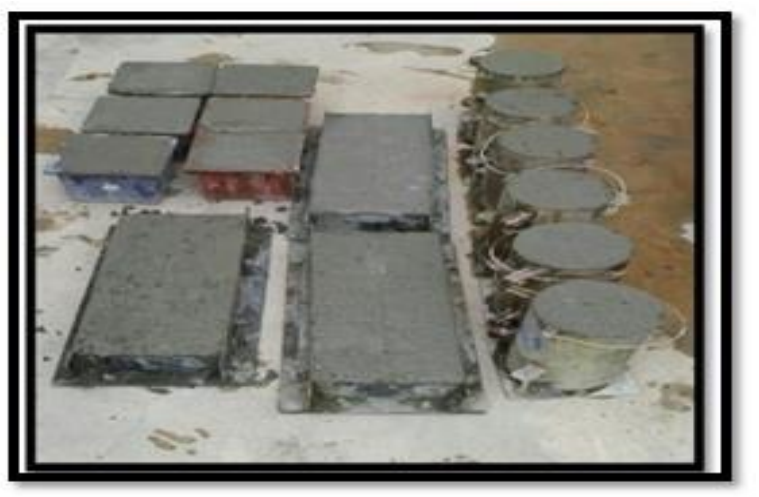

Fig. 1. Casting of concrete specimens

\subsection{Curing of samples}

Curing is the process of controlling the rate of moisture loss by providing continuous moisturizing of the concrete in order to obtain good concrete quality. This is created by providing a suitable environment for the curing to obtain the appropriate strength because the quantity and rate of humidity depends on the temperature and humidity of the concrete sample. Three kinds of curing were used: the curing with immersed in normal water at temperature $35^{\circ} \mathrm{C}$, curing by immersing in hot water at temperature $90^{\circ} \mathrm{C}$ for a period of five hours per day at the age of 28 days according to specifications ASTM C684 [8], where a metal basin is equipped with two electric heaters and the basin is equipped with a metal cover to maintain the temperature of water, and finally the curing by hot steam for 5 hours continuously daily and for 28 days according to specifications ASTM C684 [8], where a thick cloth room is equipped with 
dimensions of cubic meter connected to a steam generator that works on electric power and generates relative humidity of $95 \%$ and temperature degree $95^{\circ} \mathrm{C}$.

\subsection{Studied variables}

As mentioned previously, the variables studied in the current research are the method of concrete curing as well as the percentage of silica fumet, where three ratios of silica fume were used for each curing method in addition to the reference reactive powder concrete free of silica fume, see Table (8).

Table 8. Studied variables of RPC specimens

\begin{tabular}{|c|c|c|c|}
\hline $\begin{array}{l}\text { Group } \\
\text { No. }\end{array}$ & $\begin{array}{l}\text { Specimen } \\
\text { No }\end{array}$ & curing & $\begin{array}{c}\text { Silica fume add } \\
\%\end{array}$ \\
\hline \multirow{3}{*}{ G1 } & $\mathrm{S} 1$ & $35^{\circ} \mathrm{C}$ & 0 \\
\hline & $\mathrm{S} 2$ & $90^{\circ} \mathrm{C}$ & 0 \\
\hline & S3 & steam & 0 \\
\hline \multirow{3}{*}{ G2 } & $\mathrm{S} 1$ & $35^{\circ} \mathrm{C}$ & 5 \\
\hline & S2 & $90^{\circ} \mathrm{C}$ & 5 \\
\hline & S3 & steam & 5 \\
\hline \multirow{3}{*}{ G3 } & $\mathrm{S} 1$ & $35^{\circ} \mathrm{C}$ & 10 \\
\hline & $\mathrm{S} 2$ & $90^{\circ} \mathrm{C}$ & 10 \\
\hline & S3 & steam & 10 \\
\hline \multirow{3}{*}{ G4 } & S1 & $35^{\circ} \mathrm{C}$ & 15 \\
\hline & $\mathrm{S} 2$ & $90^{\circ} \mathrm{C}$ & 15 \\
\hline & S3 & steam & 15 \\
\hline \multirow{3}{*}{ G5 } & $\mathrm{S} 1$ & $35^{\circ} \mathrm{C}$ & 0 \\
\hline & $\mathrm{S} 2$ & $90^{\circ} \mathrm{C}$ & 0 \\
\hline & $\mathrm{S} 3$ & steam & 0 \\
\hline \multirow{3}{*}{ G6 } & $\mathrm{S} 1$ & $35^{\circ} \mathrm{C}$ & 5 \\
\hline & $\mathrm{S} 2$ & $90^{\circ} \mathrm{C}$ & 5 \\
\hline & S3 & steam & 5 \\
\hline \multirow{3}{*}{ G7 } & S1 & $35^{\circ} \mathrm{C}$ & 10 \\
\hline & $\mathrm{S} 2$ & $90^{\circ} \mathrm{C}$ & 10 \\
\hline & S3 & steam & 10 \\
\hline \multirow{3}{*}{ G8 } & $\mathrm{S} 1$ & $35^{\circ} \mathrm{C}$ & 15 \\
\hline & $\mathrm{S} 2$ & $90^{\circ} \mathrm{C}$ & 15 \\
\hline & S3 & steam & 15 \\
\hline
\end{tabular}

\section{Hardened concrete tests}

\subsection{Compressive strength test}

The compressive strength was conducted according to BS 1581: Part 116: 1983] [14] for cubes $(150 * 150 *$ 150) $\mathrm{mm}$ where it was loaded axially using a (U-Test) machine of capacity $(2025 \mathrm{KN})$ with loading rate of $(7 \mathrm{kN} / \mathrm{sec})$, so that the load is on the opposite sides of the cube and vertical to the direction of casting, the rate of three cubes strength was adopted at the age of $(7,28)$ days considered from the time of adding water to the mixture, Fig. (2).

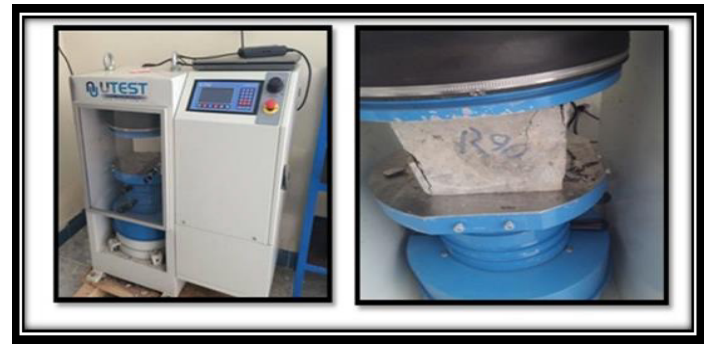

Fig. 2. Compressive Test of Concrete Cubes

\subsection{Splitting strength test}

ASTM C 496-96 [15] was adopted to conduct the splitting strength test on 28-day cylindrical specimens with standard dimensions $(300 * 150)$ using an electrical test machine (U-TEST). The average of three specimens for each type of RPC mix was adopted, Fig. (3).

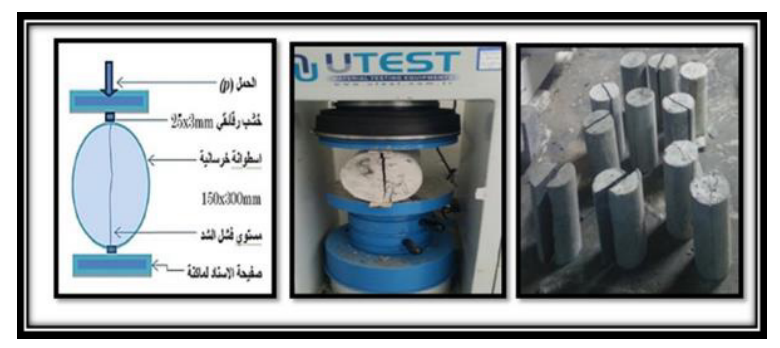

Fig. 3. Split Test of concrete cylinder

\subsection{Modulus of rupture test}

Concrete prisms of dimensions $(500 * 100 * 100) \mathrm{mm}$ were used to measure the modulus of rupture $\left(f_{r}\right)$ of RPC by using the third point loading method according to (ASTM C78-02) [16]. The average of results of three prisms for each RPC mix at the age of (28) day was adopted. The test is conducted using a (U-TEST) machine with a capacity of $300 \mathrm{kN}$ and a load ratio of 1 $\mathrm{MPa} / \mathrm{min}$, Fig. (4).

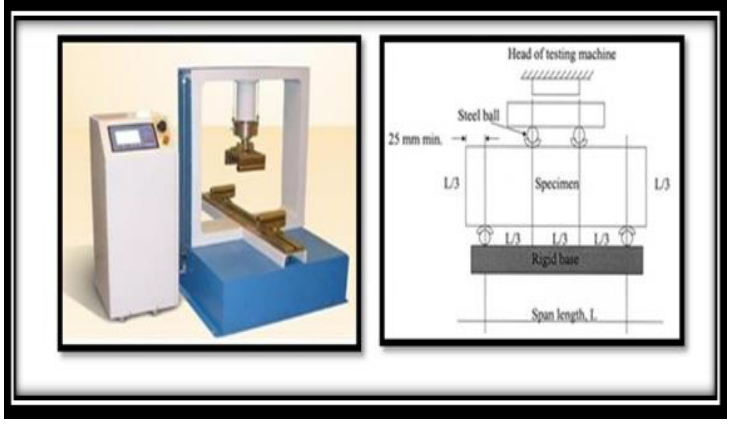

Fig. 4. Prism Test

\section{Results and discussion}

5.1 Compressive strength 
The average of three cubes strength $\mathrm{f}_{\mathrm{c}}$ was adopted for the compressive strength tests. Figures (5) and (6) shows the results for the compressive strength at 7 and 28 days age for different silica fume ratios under different curing conditions. Results showed that increasing of silica fume ratio significantly increases the compressive resistance of concrete cubes to all concrete mixes compared with the reference concrete mix which is free of silica dust, where the curing by immersing in water with $35^{\circ} \mathrm{C}$ with $5 \% \mathrm{SF}$ increases the compressive strength by $(4.1 \%$, $7.07 \%$ ) for concrete cubes at age of 7 and 28 days respectively, and for $10 \%$ S.F, the increase was $9.7 \%$ and $10.08 \%$ at 7 days and 28 days respectively. When adding $15 \%$ of the S.F, this leads to decrease in compressive strength by $(2 \%, 2.5 \%)$ for 7 and 28 days age respectively.

When using the curing by hot water immersing at 90 ${ }^{\circ} \mathrm{C}$ method with adding $5 \%$ of S.F, this leads to increases in compressive strength by $(34.5 \%, 32.7 \%)$ for ages of $(7,28)$ days respectively. Adding $10 \%$ of silica dust increases $\mathrm{f}_{\mathrm{c} \text { by }}(41.9 \%, 37.1 \%)$ for ages of $(7,28)$ days respectively. Adding $15 \%$ of silica fume results in a decrease in compressive strength of $26 \%$ and $19.3 \%$ for concrete cubes with 7 days and 28 days respectively.

For the steam method of curing with adding 5\% S.F, this will lead to an increas in compressive strength by $(2 \%, 8.7 \%)$ for ages of $(7,28)$ days respectively. When adding $10 \%$ of S.F, this leads to an increas in compressive strength by $(10.6 \%, 14.2 \%)$ for ages of $(7$, 28 ) days respectively, and when adding $15 \%$ of S.F, the increasing in compressive strength will be $(25 \%, 35 \%)$ for ages of $(7,28)$ days respectively. The increasing of compressive strength values with increasing of S.F percentages can be attributed to the reason that the S.F is a very fine material that penetrates between the granules of cement and the quartz sand, reduces voids and increase the density. Also, the pozzolanic activity of this material causes more hydration process which leads to more strength and producing the gel, which increases the density of concrete, and thus, increasing the compressive strength. For the effects of different treatments on the compressive strength for constant S.F ratios, and considering the curing by water at $35^{\circ} \mathrm{C}$ is the reference curing method, the effects is as follow: When the S.F ratio is $0 \%$, the accelerated curing contributes to the increased compressive strength of the concrete by ratios $(24 \%, 14.6 \%)$ for curing by hot water of temperature degree $90^{\circ} \mathrm{C}$ and for steam curing respectively for 7 days age, and the percentage increase is $(13.6 \%, 17.6 \%)$ for curing by hot water of temperature degree $90^{\circ} \mathrm{C}$ and for steam curing respectively for 28 days. For 5\% S.F ratio, accelerated treatment contributes to an increased compressive strength as the percentage increase is $(17.4 \%, 42)$ for curing by hot water of temperature degree at $90^{\circ} \mathrm{C}$ and for steam curing respectively for 7 days age, and the percentage increase is $(22.8 \%$, $44.22 \%$ ) for hot water curing at $90^{\circ} \mathrm{C}$ and steam treatment respectively at 28 days. When the percentage of S.F is $10 \%$, accelerated treatment contributes to an increased compressive strength as the percentage increase is $(41 \%, 63.4 \%)$ for hot water curing $90^{\circ} \mathrm{C}$ and steam curing respectively at 7 days, and with increasing percentage of $(23.8 \%, 42.75 \%)$ for hot water curing $90^{\circ}$ $\mathrm{C}$ and steam curing respectively at 28 days, At the rate of addition of S.F $15 \%$, the accelerated curing contributes to the increase of compressive resistance but with very slight percentage increase of $(0.05 \%, 1 \%)$ for hot water curing $90^{\circ} \mathrm{C}$ and steam curing respectively at 7 days, either in case of the accelerated curing at the ages of 28 days, the accelerated curing has a negative effect on compressive strength as the percentage of reduction is (25\%, 20\% for hot water curing $90^{\circ} \mathrm{C}$ and steam curing respectively. From the above values, it can be concluded that accelerated curing using immersing in $90^{\circ} \mathrm{C}$ hot water method improves the compressive strength compared with steam-accelerated curing and reference curing method.

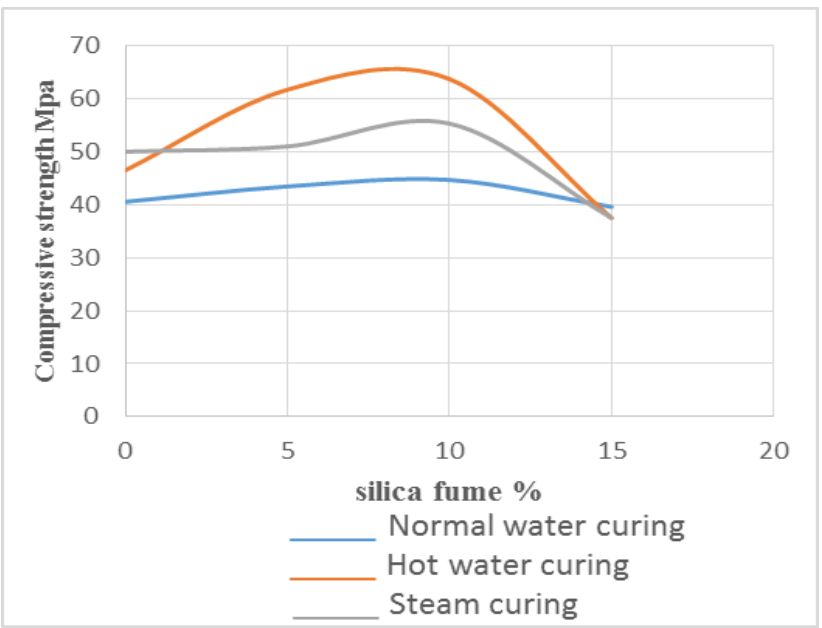

Fig. 5. Relationship between silica percentage and compressive strength at 7 days

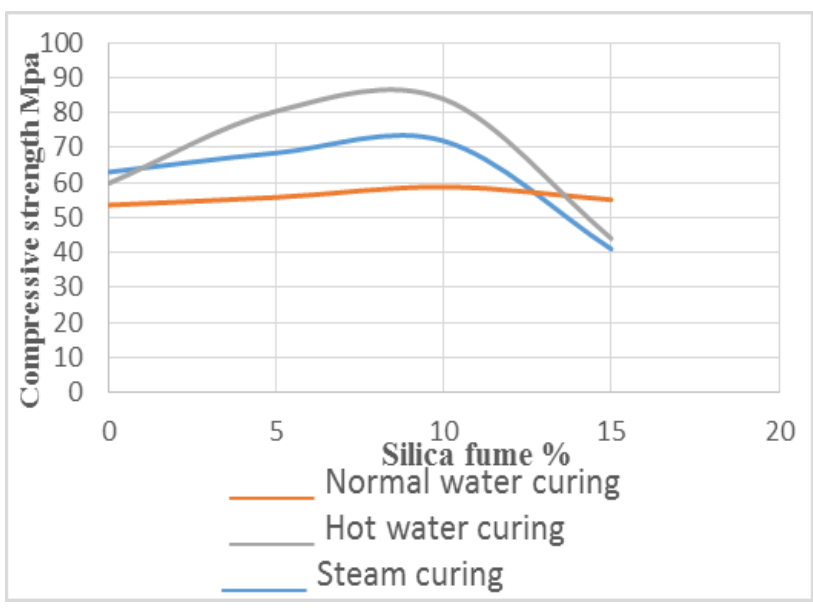

Fig. 6. Relationship between silica percentage and compressive strength at 28 days

\subsection{Split tensile strength}

The results showed, Figure (7), that the addition of S.F results in an increase in the tensile strength of the RPC cylinders. Considering that the curing with water at $35^{\circ} \mathrm{C}$ 
temperature is the reference curing, the effect of silica fume on splitting strength is as follows: adding S.F increases the tensile strength by $(14 \%, 137.5 \%, 80.3 \%)$ for S.F percentages $(15 \%, 10 \%, 5 \%)$, respectively comparing with RP contains no S.F. When applying a hot water at $90^{\circ} \mathrm{C}$ curing, the addition of S.F increases the tensile strength by $(25.5 \%, 38.4 \%)$ for the S.F addition $(5 \%, 10 \%)$. But it decreases by about $(40 \%)$ when adding $15 \%$ of S.F.

Either by steam curing, this will leads to increases of tensile strength by $(214.1 \%, 243.9 \%, 33.3 \%)$ for the addition of S.F (5\%, 10\% and 51\%), respectively. As for the effect of different curing methods on the tensile strength values, with constant S.F ratio, when the concrete is free of S.F, the percentage of increase in the splitting tensile strength was $(1 \%, 135.9 \%)$ for hot water curing at $90^{\circ} \mathrm{C}$ and steam curing respectively. In the case of $5 \%$ S.F ratio, the increase in tensile strength was $(63.77 \%, 38.8 \%)$ for hot water curing of $90^{\circ} \mathrm{C}$ and steam curing respectively.

For $10 \%$ of S.F ratio, the percentage of increase in splitting tensile strength is $(35.7 \%, 15.27 \%)$ for hot water curing of $90^{\circ} \mathrm{C}$ and steam curing respectively and for $15 \%$ of S.F, then the increase splitting tensile strength is $34.4 \%$ for hot water curing of $90^{\circ} \mathrm{C}$, but in steam curing method, there was a decrease in splitting tensile strength by about $7 \%$. The results indicated that increase addition of S.F from $5 \%$ to $10 \%$ had a positive effect on the splitting tensile strength $\mathrm{f}_{\mathrm{t}}$.

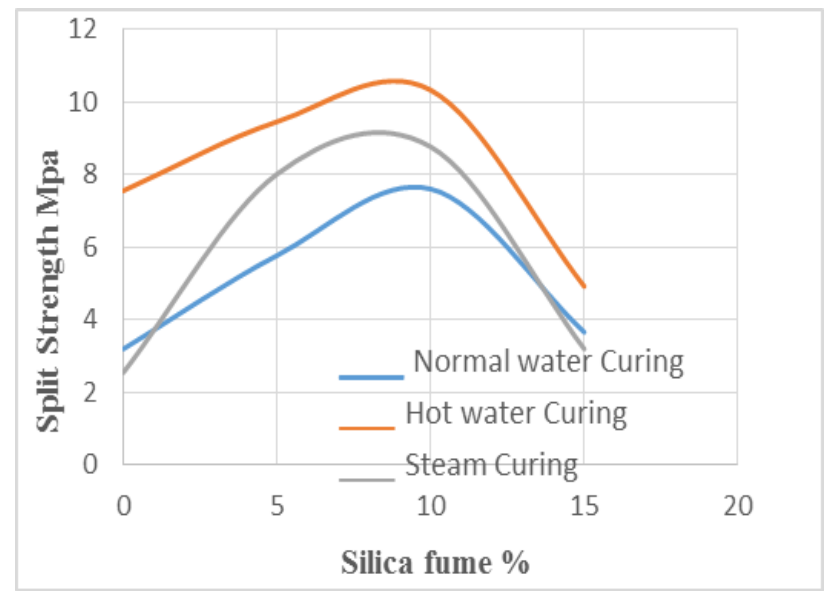

Fig. 7. Split tensile strength results

\subsection{Modulus of rupture}

The experimental program results, Figure (8) showed that the effect of the change in the addition of S.F and the effect of the change in the curing methods is as follows: when the immersion in water at $90^{\circ} \mathrm{C}$ curing method is used, then the increase S.F ratio contributes to the increase in modulus of rupture by $(36.9 \%$ and $26.7 \%)$ for the addition ratio $(5 \%$ and $10 \%)$ respectively. However, a decrease of $(8.9 \%)$ is occurred for S.F ratio of $15 \%$, and when the hot water at $90^{\circ} \mathrm{C}$ curing method is used, then the increase S.F ratio contributes to the increase of the modulus of rupture by $(36.9 \%, 31 \%$, $26.7 \%)$ for the S.F addition ratios $(15 \%, 10 \%, 5 \%)$ respectively, and for the steam curing method, the increase in the silica dust additive content contributes to the increase in the modulus of rupture by $(51.4 \%, 21.3 \%$, $12.6 \%)$ for the S.F addition ratios $(15 \%, 10 \%, 5 \%)$ respectively.

Either the effect of different treatment methods on modulus of rupture values is as follows: when the concrete is free of S.F and cured with hot water at $90^{\circ} \mathrm{C}$ and steam curing, the modulus of rupture values increase by $(1 \%, 48.7 \%)$, where the increase in $f_{r}$ due to steam curing method was very slight compared to increase due to hot water curing method. At the percentage of $5 \%$ of S.F and when the RPC is cured by hot water at $90^{\circ} \mathrm{C}$ and cured by steam method, the values of modulus of rupture increased by $(44.4 \%, 0 \%)$, and as noted, the steam curing method have no effect in $f_{r}$ increase. At the percentage of $10 \%$ of S.F and when the RPC is cured by hot water at $90^{\circ} \mathrm{C}$ and cured by steam method, the values of modulus of rupture increased by $(12.1 \%, 96.5 \%)$ respectively, and when $15 \%$ ratio of S.F is used, and the $\mathrm{RPC}$ is cured with hot water at $90^{\circ} \mathrm{C}$ and with steam method, the values of modulus of rupture is increased by $(22.3 \%, 30.9 \%)$ respectively.

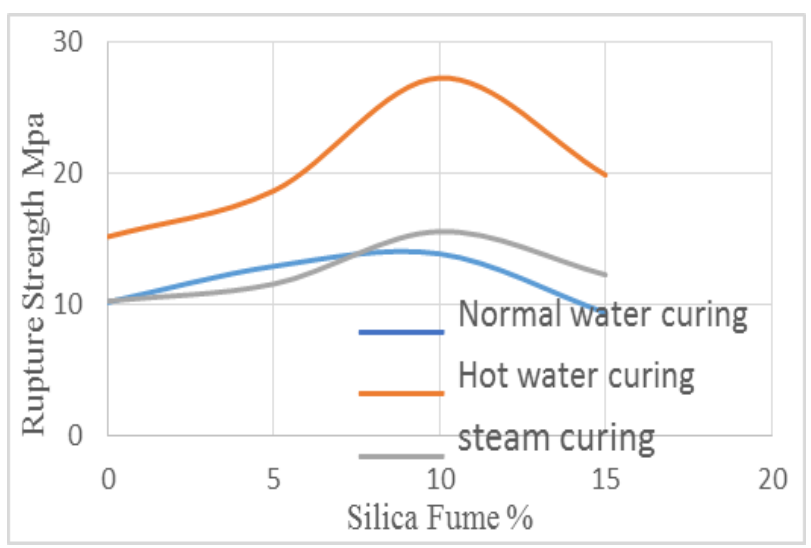

Fig. 8. Modulus of rupture results

Table. 9. Compressive strength, split tensile strength and modulus of rupture at 28 days age

\begin{tabular}{ccccc}
\hline \hline $\begin{array}{c}\text { Curing } \\
\text { Method }\end{array}$ & $\begin{array}{c}\text { Silica } \\
\text { Fume } \\
\%\end{array}$ & $\begin{array}{c}\text { Compressive } \\
\text { Strength for } \\
\text { cubes } \mathrm{f}_{\text {cu }} \\
(\mathrm{MPa})\end{array}$ & $\begin{array}{c}\text { Split } \\
\text { Tensile } \\
\text { Strength } \\
\text { for } \\
\text { Cylinders } \\
\mathrm{f}_{\mathrm{t}}(\mathrm{MPa})\end{array}$ & $\begin{array}{c}\text { Modulus } \\
\text { of } \\
\text { Rupture } \\
\mathrm{f}_{\mathrm{r}}(\mathrm{MPa})\end{array}$ \\
\hline Immersion & 0 & 53.55 & 3.2 & 10.22 \\
in water & 5 & 55.78 & 5.77 & 12.95 \\
$35^{\circ} \mathrm{C}$ & 10 & 58.77 & 7.6 & 13.9 \\
& 15 & 55.1 & 3.66 & 9.4 \\
\hline Immersion & 0 & 59.79 & 7.55 & 15.2 \\
in hot & 5 & 80.45 & 9.45 & 18.7 \\
water & 10 & 83.9 & 10.32 & 27.3 \\
$90^{\circ} \mathrm{C}$ & 15 & 44 & 4.92 & 19.9 \\
\hline & 0 & 63 & 2.55 & 10.3 \\
steam & 5 & 68.5 & 8.01 & 11.6 \\
& 10 & 71.9 & 8.76 & 15.6 \\
& 15 & 41 & 3.2 & 12.3 \\
\hline \hline
\end{tabular}




\section{Conclusions}

1. (Reactive Powder Concrete can be product by using silica fume, quartz sand with mixing ratio $(1: 1.1)$ (cement:quartz sand) with cement content of $990 \mathrm{~kg}$ $/ \mathrm{m}^{3}$, w/c equal to 0.24 ratio, and an addition ratios of silica fume $(0 \%, 5 \%, 10 \%, 15 \%)$ from the weight of cement and super-plasticized content $1.8 \%$ from the weight of cementations materials.

2. Accelerated methods of curing using hot water at $90^{\circ} \mathrm{C}$ and steam for 5 hours per day allow a better contribution in improvement of the mechanical properties of hardened reactive powder concrete (compressive strength, indirect tensile strength $\mathrm{f}_{t}$, modulus of rupture $\mathrm{f}_{\mathrm{r}}$ ) compared with waterimmersed curing at a temperature of $35^{\circ} \mathrm{C}$. The immersion in hot water at $90^{\circ} \mathrm{C}$ is better than steam curing method to improve the mentioned properties.

3. For the various curing methods mentioned, the best addition ratio of silica fume in improving the mechanical properties of concrete (compressive strength, indirect tensile strength $f_{t}$, modulus of rupture $\left.f_{r}\right)$ is the ratio of $(10 \%)$.

\section{References}

1. P. Richard and M. H. Cheyrezy, Proceedings of the $V$. Mohan Malhotra Symposium, ACI, SP-144, S. Francisco. No.4, pp.507-518, (1994)

2. D. Jeong and H. Lee, international Conference on sustainable Building ,Asia, Seoul.

3. W. Shuxin, and C. Victor Li., ACI Materials Journal, pp. 97-105, (2006)

4. M. Dashti Rahmatabadi, International Journal of Structural and Civil Engineering Research Vol. 4, No. 4, pp.354-358,(2015)

5. F. Hattatoglou and A. Bakis, World Academy of Science, Engineering and Technology, International Journal of Civil, Environmental, Structural, Construction and Architectural, Vol.10, No.4, pp.503-507, (2016)

6. N. Al-.Jubory, civil Eng. department, University of Mosul (2015)

7. N.P. Lee and D.H. Chisholm, Study Report No. 146, Building Research Levy, New Zealand, pp. 1-29, (2005)

8. ASTM C684-(2003), Standard Test Method for Making, Accelerated Curing, and Testing Concrete Compression Test Specimens, http://www.astm.org/Standards/C684.htm
9. Iraqi specification, No.5/1984., "Portland cement"

10. B.S.882, "Specification for Aggregates from Natural Sources for Concrete", British Standards Institution, (1992)

11. ASTM C1240 -03, "Standard Specification for Use of Silica Fume as a Mineral Admixture in HydraulicCement Concrete, Mortar, and Grout" (2003)

12. Superplasticizer, pc260, for DCP company, product data sheet, http://www.dcp-int.com/psmenaenglish.

13. ACI Committee 211-91 ""Standard Practice for Selecting Proportions for Normal, Heavyweight, and Mass Concrete" (ACI 211.1-91) (Reapproved 2009), American Concrete Institute, (1991)

14. B.S. 1881 Part 116 "Method for Determination of Compressive Strength of Concrete Cubes" British Standards Institution, (1989)

15. ASTM C 496 - 96 "Standard Test Method for Splitting Tensile Strength of Cylindrical Concrete Specimens manual book of ASTM standards، Vol. 04, No.2, pp-36-38, (2004)

16. ASTM designation C78-02،"Standard test method for flexural strength of concrete (using samples beam with third point loading) (2002) 